\title{
Scaling of spike-timing based neuron model for mammalian olfaction with network size
}

\author{
Bolun Chen ${ }^{1}$, Jan R Engelbrecht ${ }^{1}$, Renato Mirollo ${ }^{2}$ \\ From The Twenty Third Annual Computational Neuroscience Meeting: CNS*2014 \\ Québec City, Canada. 26-31 July 2014
}

We investigate extensions to the model put forward by Brody and Hopfield [1] for spike-timing based pattern recognition applied to mammalian olfaction. Their model implements a pattern recognition algorithm realized in the dynamics of a network of coupled IF neurons subject to a sine-wave rhythm. Subsets of these neurons can synchronize through the principle of one-to-one mode locking. Their network represents 3 layers of neural activity, the first two of which are inspired by the connectivity of glomeruli and mitral cells in mammalian olfactory circuits and the gamma-rhythm activity observed in the olfactory bulb. Specifically in this model a pattern of glomerular activity representing a given odor causes a particular subset of model mitral cells to synchronize and this synchronous activity can drive a "grandmother" model cortical cell through threshold triggering a recognition event. In this study we quantify the performance of their original model and compare it to our extensions of the model such as using a network-generated rhythm rather than a sinewave, introducing inhibitive feedback and generalizing to $\mathrm{p}-\mathrm{q}$ mode locking strategies. We compute the scaling with respect to the number of mitral neurons of a measure of the number of odor patterns the model can recognize. Quite remarkably we find this performance can increase very fast with increasing network size - consistent with exponential scaling.

\section{Authors' details}

'Physics Department, Boston College, Chestnut Hill, MA 02467, USA.

${ }^{2}$ Mathematics Department, Boston College, Chestnut Hill, MA 02467, USA.

Published: 21 July 2014

'Physics Department, Boston College, Chestnut Hill, MA 02467, USA

Full list of author information is available at the end of the article
Reference

1. Brody CD, Hopfield JJ: Simple Networks for Spike-Timing-Based Computation, with Application to Olfactory Processing. Neuron 2003, 37:843-852.

doi:10.1186/1471-2202-15-S1-P90

Cite this article as: Chen et al:: Scaling of spike-timing based neuron model for mammalian olfaction with network size. BMC Neuroscience 2014 15(Suppl 1):P90.
Submit your next manuscript to BioMed Central and take full advantage of:

- Convenient online submission

- Thorough peer review

- No space constraints or color figure charges

- Immediate publication on acceptance

- Inclusion in PubMed, CAS, Scopus and Google Scholar

- Research which is freely available for redistribution

Submit your manuscript at www.biomedcentral.com/submit
() Biomed Central

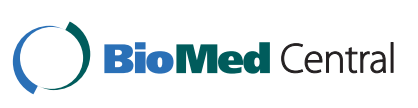

(C) 2014 Chen et al; licensee BioMed Central Ltd. This is an Open Access article distributed under the terms of the Creative Commons Attribution License (http://creativecommons.org/licenses/by/4.0), which permits unrestricted use, distribution, and reproduction in any medium, provided the original work is properly cited. The Creative Commons Public Domain Dedication waiver (http:// creativecommons.org/publicdomain/zero/1.0/) applies to the data made available in this article, unless otherwise stated. 